\title{
Pola Penguasaan Tanah Sawah Secara Gilir Ganti dalam Perspektif Hukum Agraria
}

\author{
Isran Idris, ${ }^{\star}$ Taufik Yahya, ${ }^{\star \star}$ Windarto ${ }^{\star \star \star}$ \\ ${ }^{\star}$ Fakultas Hukum Universitas Jambi \\ isranidris3@gmail.com

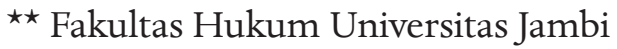 \\ taufik_yahya@unja.ac.id \\ $\star \star \star$ Fakultas Hukum Universitas Jambi \\ mas_wiend@unja.ac.id
}

\begin{abstract}
Gilir ganti sawah system is model of authority and ownership of land base on adat law in district Kerinci, Jambi. The article analize outhority and ownership model of fild rice land with alternate manner in agrarian law perspective. This research has done by observation, interview, literature study. The result of research point out, sistem gilir ganti sawah is side effect of kinship and legacy/ inheritance system to differentiate between son and dauhtor. The wet rice fild land is done and takken by daughter, but the regulation by tengganai (brother from mother line). More and more heirees, make more and more duration of waiting. For the third level or more, sistem gilir ganti sawah to be ineffective, unproductive, and there is no law certenty and easy conflict. Base on agrarian law perspective, the authority and ownership make difficult to determine the owner, so immposible to register for secticate. But this model stil stand and has been stand up with the reason as be indication that they are one clan.
\end{abstract}

Keywords: rice land; gilir ganti; agrarian law; Kerinci 


\section{Abstrak}

Sistem gilir ganti sawah merupakan pola penguasaan dan pemilikan tanah berdasarkan hukum adat di wilayah Kerinci, Jambi. Artikel ini membahas pola penguasaan dan pemilikan tanah sawah secara gilir ganti dalam perspektif hukum agraria. Penelitian ini dilakukan melalui pengamatan, wawancara, dan studi literatur. Hasil penelitian menunjukkan, sistem gilir ganti sawah dipengaruhi oleh sistem kekerabatan dan kewarisan yang membedakan antara anak laki-laki dan anak perempuan. Tanah sawah dikerjakan dan dinikmati oleh anak perempuan, sedangkan pengaturannya oleh tengganai (saudara laki-laki dari pihak ibu). Semakin banyak ahli waris perempuan, maka semakin lama masa tunggu. Pada tingkat lapisan ketiga atau lebih, sistem gilir ganti sawah menjadi tidak efektif, tidak produktif, tidak memiliki kepastian hukum, dan rawan akan konflik. Dari perspektif hukum agraria nasional, pola penguasaan tanah secara demikian menyebabkan sulit untuk menetapkan subjek hukum pemiliknya, sehingga tidak memungkinkan untuk didaftarkan guna mendapatkan sertifikat. Meski begitu, sistem ini masih tetap bertahan dan dipertahankan dengan alasan sebagai penanda satu keturunan keluarga.

Kata Kunci: tanah sawah; gilir ganti; hukum agraria; Kerinci

\section{A. Pendahuluan}

Artikel ini membahas pola penguasaan tanah sawah berdasarkan sistem gilir ganti. Sistem gilir ganti sendiri adalah pola penguasaan dan pemilikan tanah berdasarkan hukum adat di wilayah Kabupaten Kerinci, Provinsi Jambi. Dengan gilir ganti, maka penguasaan tanah sawah dilakukan secara bergilir ganti di antara anak batino (perempuan). Dalam artikel ini, sistem gilir ganti akan ditelaah berdasarkan perspektif hukum agraria.

Ada dua alasan yang mendasari mengapa penelaahan gilir ganti pengelolaan tanah sawah dari perspektif hukum agraria menjadi penting. Pertama, sistem gilir ganti merupakan bagian dari hukum adat yang sampai saat ini berlaku di wilayah Kabupaten Kerinci Provinsi Jambi. Sebagai bagian dari hukum yang hidup (living law), gilir ganti berlangsung secara turun-temurun dan sulit dilacak awal mulanya, 
kecuali dikatakan telah ada sejak masa nenek moyang orang Kerinci. ${ }^{1}$ Karena ia muncul dan tumbuh di masyarakat, bahkan hidup dalam artian masih dijalankan dan dipedomani oleh masyarakat, maka keberlakuannya bernilai sebagai hukum, sehingga dikategorikan sebagai bagian dari hukum adat. ${ }^{2}$

Dengan sistem gilir ganti, pola penguasaan tanah sawah dilakukan secara bergilir ganti di antara anak perempuan. Sawah gilir ganti sendiri merupakan harta warisan yang tidak dibagi dalam artian beralih kepemilikannya pada ahli waris, melainkan pemanfaatannya digilir ganti di antara ahli waris anak perempuan. Dengan demikian, tanah sawah hanya berganti subyek yang memanfaatkannya, bukan yang memilikinya.

Kedua, penguasaan tanah merupakan bagian dari ruang lingkup peraturan hukum agraria, yang di Indonesia diatur dengan Undangundang Nomor 5 Tahun 1960 tentang Peraturan Dasar Pokok-pokok Agraria (UUPA). UU ini, yang sudah berlaku hampir 60 tahun, menjadi tonggak awal hukum agraria nasional ${ }^{3}$ dalam menghilangkan

1 Sebagaimana disebut Idris Djakfar, ketentuan hukum tanah adat di Kerinci telah ada sejak lahirnya Negara Segindo Alam Kerinci, dan pada akhir abad ke 13 dilanjutkan oleh Negara Depati Empat Alam Kerinci hingga sampai permulaan abad ke 20. Idris Djakfar, "Hukum Waris Adat Masyarakat Kerinci”, Laporan Penelitian, Fakultas Hukum Universitas Jambi, 1992, hlm. 53-55. Menurut Adrian Sutedi (Peralihan Hak atas Tanah dan Pendaftarannya, [Jakarta: Sinar Grafika, 2016], hlm. 31) tanah adat merupakan milik dari masyarakat hukum adat yang dikuasai sejak dahulu.

2 Hukum adat merupakan hukum yang lahir dari nilai-nilaibudaya masyarakat adat sebagai cerminan dari sesuatu yang dianggap benar, patut, dan baik dalam menata hubungan-hubungan mereka dengan lingkungan sosialnya maupun lingkungan alam fisiknya seperti tanah. Hukum adat dalam hal ini merupakan hukum asli masyarakat Indonesia yang tidak berbentuk perundang-undangan yang mengandung unsur-unsur agama. Hilman Hadikusuma, Pengantar Ilmu Hukum Adat Indonesia (Bandung: Mandar Maju, 1994), hlm. 32; M. Syamsudin, "Beban Masyarakat Adat Menghadapi Hukum Negara”, Jurnal Hukum Ius Quia Iustum, 15, 3 (2008), hlm. 340.

3 UUPA sebagai induk reforma agraria belum mampu menjadi jawaban atas permasalahan agraria di Indonesia. Hal ini disebabkan karena banyak amanat di dalamnya yang belum dilaksanakan, dan aturan-aturan di bawahnya yang bertentangan dengan Pancasila dan UUD 1945. Yanis Maladi, "Reforma Agraria Berparadigma Pancasila dalam Penataan Kembali Politik Agraria Nasional", Mimbar Hukum, 25, 1 (2013), hlm. 27. 
dualisme hukum yang berlaku sebelumnya disebabkan memberlakukan hukum adat dan hukum agraria barat. UU ini bermaksud menjamin kepastian hukum bagi seluruh rakyat Indonesia dengan mengadakan kesatuan hukum. ${ }^{4}$

Meski hendak menyatukan hukum secara nasional, bukan berarti UUPA menghilangkan keberlakuan hukum adat, ${ }^{5}$ yang karena sifat mengikatnya pada wilayah hukum adat menjadikannya bisa berbeda-beda antar wilayah. UUPA justru menegaskan, hukum adat boleh diberlakukan dalam masyarakat namun sepanjang tidak bertentangan dengan kepentingan nasional dan negara dan peraturan yang ada di atasnya. ${ }^{6}$

Dalam kaitan dengan dua alasan tersebut, maka patut mendapat perhatian, bahwa pada gilir ganti sawah tidak terlihat dengan tegas penguasaan dan kepemilikan antara subjek hukum dan objek hukum baik secara fisik dan yuridis, sementara UUPA menghendaki adanya kepastian hukum: kepastian subjek hukum, kepastian objek hukum, kepastian perbuatan hukum, dan kepastian hubungan hukum. Berba-

4 Lihat Penjelasan Umum UUPA.

5 Secara umum tidak terbatas pada tanah, keberadaan hukum adat sebagai salah satu sumber hukum di Indonesia memang semakin terpinggirkan. Salah satunya disebabkan anggapan bahwa hukum adat sangat bersifat tradisional dan tidak dapat menjangkau perkembangan jaman (globalisasi dan teknologi). Implikasinya, dalam pemecahan permasalahan di masyarakat sering menafikan hukum adat, yang sebenarnya lebih relevan. Lastuti Abubakar, "Revitalisasi Hukum Adat Sebagai Sumber Hukum dalam Membangun Sistem Hukum Indonesia”, Jurnal Dinamika Hukum, 13, 2 (2013), hlm. 320.

6 Pasal 5 UUPA: "Hukum agraria yang berlaku atas bumi, air dan ruang angkasa ialah hukum adat, sepanjang tidak bertentangan dengan kepentingan nasional dan negara, yang berdasarkan atas persatuan bangsa, dengan sosialisme Indonesia serta dengan peraturan-peraturan yang tercantum dalam UU ini dan dengan peraturan perundangan lainnya, segala sesuatu dengan mengindahkan unsur-unsur yang bersandar pada hukum agama”. Pasal 3 UUPA: "Dengan mengingat ketentuan-ketentuan dalam Pasal 1 dan 2 pelaksanaan hak ulayat dan hak-hak yang serupa itu dari masyarakat-masyarakat hukum adat, sepanjang menurut kenyataannya masih ada, harus sedemikian rupa sehingga sesuai dengan kepentingan nasional dan negara, yang berdasarkan atas persatuan bangsa serta tidak boleh bertentangan dengan UU dan peraturan-peraturan lain yang lebih tinggi”. 
gai kepastian hukum tersebut didapatkan melalui pendaftaran tanah, ${ }^{7}$ sehingga jelas penguasan tanah baik secara fisik maupun yuridis.

Berdasarkan uraian tersebut perlu dikaji bagaimana upaya memberi kepastian hukum pada masyarakat (lokal) yang masih menggunakan hukum adat dalam pengaturan pertanahan, sebagaimana halnya masyarakat Kerinci dengan sistem gilir ganti. Walaupun keberlakuan hukum tanah adat diakui sah dalam hukum agraria nasional, termasuk pengaturan sawah gilir ganti, keberlakuan tersebut perlu dikaji terkait tuntutan hukum dan kebutuhan masyarakat sekarang dalam mengantisipasi dan menyelesaikan konflik pertanahan. Dalam artikel ini, keberlakuan hukum adat berupa gilir ganti ditelaah berdasarkan hukum agraria nasional. Pengamatan (observasi), wawancara dengan tokoh adat dan pimpinan Badan Pertanahan Nasional Kerinci, serta studi literatur terkait hukum adat, digunakan dalam penelitian ini. Dalam membahasnya, artikel ini setelah bagian ini dilanjutkan dengan uraian penguasaan dan pemilikan hak atas tanah menurut hukum adat, sistem gilir ganti sawah di Kerinci, tinjauan sistem gilir ganti berdasarkan hukum agraria, dan penyimpulan.

\section{B. Penguasaan dan pemilikan Hak Atas Tanah Menurut Hukum Adat}

Hubungan antara tanah dan manusia atau masyarakat terjalin dengan erat, yang melahirkan suatu kehidupan bersama yang dikenal dengan masyarakat hukum adat. ${ }^{8}$ Dalam pemanfaatan tanah berlaku

7 Pasal 19 ayat(1)UUPA: "Untuk menjamin kepastian hukum oleh Pemerintah diadakan pendaftaran tanah di seluruh wilayah Republik Indonesia menurut ketentuan-ketentuan yang diatur dengan Peraturan Pemerintah”. Pasal 19 ayat (2) UUPA: "Pendaftaran tersebut dalam ayat (1) pasal ini meliputi: a. pengukuran perpetaan dan pembukuan tanah; b. pendaftaran hak-hak atas tanah dan peralihan hak-hak tersebut; c. pemberian surat-surat tanda bukti hak, yang berlaku sebagai alat pembuktian yang kuat”.

8 Koentjaraningrat, Kebudayaan, Mentalitet, dan Pembangunan (Jakarta: PT. Gramedia, 1987), hlm. 38. Husen Alting dengan menelitipengelolaan sumber daya alam tanah pada masyarakat hukum adat Ternate menyebutkan ada delapan ciri masyarakat hukum adat, yaitu: pertama, terdapat sumber daya alam (tanah, hutan, tambang, air) yang berada dalam wilayah masyarakat hukum adat; kedua, dimiliki dan atau dikuasai oleh sekelompok orang 
suatu norma yang mengatur tentang pemilikan dan penguasaan baik secara individu maupun kelompok. Norma tersebut terdiri dari norma yang ideal sampai kepada yang bersifat konkret, dijalankan oleh fungsionaris adat, yang menimbulkan hubungan hukum antara masyarakat dan wilayahnya, dan juga adanya pengakuan hak-hak perseorangan atas tanah.

Pengaturan tersebut menimbulkan jenis-jenis hak atas tanah, salah satunya adalah hak ulayat. Hak ulayat (beschkingrecht) adalah hak desa menurut adat dan kemauannya untuk menguasai tanah dalam lingkungan daerahnya buat kepentingan anggotanya atau untuk kepentingan orang lain (orang asing) dengan membayar kerugian kepada desa dalam hal mana desa itu sedikit banyak turut campur dengan pembukaan tanah itu dan turut bertanggung jawab terhadap perkara-perkara yang terjadi di situ yang belum dapat diselesaikan. ${ }^{9}$ Hak ulayat masyarakat hukum adat atas tanah dalam hal ini merupakan hak materiil masyarakat hukum adat. ${ }^{10}$

Tanah ulayat merupakan satu kesatuan hak atas tanah dan mempunyai dasar keagamaan, yang dimiliki oleh persekutuan hukum, dan mengatur tentang hak-hak perseorangan. Berdasarkan hal terse-

atau individu; ketiga, dikerjakan secara tetap maupun berpindah-pindah dalam wilayah hukumnya; keempat, secara turun temurun masih berada di lokasi daerah tersebut, atau telah berpindah tangan atau dialihkan; kelima, mempunyai tanda-tanda fisik berupa sawah, ladang, hutan, dan simbol-simbol berupa makam, patung, rumah-rumah adat, dan bahasa daerah; keenam, terdapat institusi adat yang mengatur penggunaan dan pemanfaatannya; ketujuh, memiliki norma yang disepakati bersama oleh masyarakat hukum adat; dan kedelapan, mempunyai bukti kepemilikan baik secara tertulis maupun melalui pengakuan oleh warga masyarakat. Husen Alting, "Penguasaan Tanah Masyarakat Hukum Adat (Suatu Kajian terhadap Masyarakat Hukum Adat Ternate)", Jurnal Dinamika Hukum, 11, 1 (2011), hlm. 96-97.

9 Iman Soediyat, "Masalah Hak Ulayat di Wilayah Bekas Keresidenan Madura”, Prasarana Seminar Pengalaman Lapangan dan Kegunaan Hasil Penelitian Madura, 1977, hlm. 8.

10 Selain hak materiil, masyarakat hukum adat juga memiliki hak imateriil, misalnya yang berkaitan dengan hak memeluk agama atau kepercayaan. Lihat: Sukirno, "Kebijakan Afirmatif Pengakuan dan Perlindungan Hakhak Masyarakat Hukum Adat”, Masalah-Masalah Hukum, 44, 3 (2015), hlm. 328. 
but maka yang boleh memanfaatkan tanah ulayat pada hakikatnya adalah masyarakat persekutuan hukum adatnya, yang diatur oleh pemangku adat, karena pemilikan terletak pada persekutuan hukum adat, persekutuanlah yang mengatur tentang hak-hak perseorangan dan kepentingan persekutuan.

Pada hakikatnya hak ulayat merupakan 1) hak kepunyaan bersama masyarakat hukum adat sebagai kebulatan seluruh warga; 2) hak terkuat masyarakat hukum adat atas tanah termasuk air, dan udara dalam lingkungan wilayah kekuasaanya yang pada asasnya tidak dapat dikurangi/dipindahtangankan; 3) hak yang memberikan kewenangan dan tugas kepada masyarakat hukum adat untuk melakukan usaha dan mengatur segala sesuatu mengenai tanah dalam hubungannya dengan manusia untuk kepentingan umum, kesejahteraan dan kebahagiaan hidup warga masyarakat. ${ }^{11}$

Di dalam hak ulayat diperkenankan adanya hak perseorangan yang diawali dengan seseorang melakukan kegiatan di atas tanah tertentu. Kegiatan tersebut terus dilakukan seperti berladang bahkan menetap di sana sehingga terlihat adanya hubungan nyata seseorang dengan tanah. Namun apabila terjadi sebaliknya, maka hak ulayat semakin kuat, hubungan timbak balik pengusaan tanah tersebut sama dengan "teori bola" oleh Teer Haar, yaitu semakin kuat hak ulayat maka semakin menipis hak individu, dan apabila hak individu semakin kuat maka hak ulayat semakin menipis.

Dalam bidang pertanahan, hak ulayat memberi wewenang kepada masyarakat hukum adat untuk mengatur dan menyelenggarakan pemanfaatan tanah, termasuk kewenangan untuk mengatur dan menentukan hubungan hukum antara orang dengan tanah serta hubungan hukum antara orang dengan perbuatan hukum yang berkaitan dengan tanah. Namun demikian, kewenangan mengatur dan memanfaatkan tanah ulayat ini seringkali tidak dapat dijalankan sebagaimana mestinya. ${ }^{12}$

11 Soediyat, "Masalah Hak Ulayat", hlm. 20.

12 Mudjiono, "Eksistensi Hak Ulayat dalam Pembangunan Daerah", Jurnal Hukum Ius Quia Iustum, 25, 11 (2004), hlm. 153-154. Menurut Muh. Afif Mahfud, untuk meningkatkan hak masyarakat hukum adat, maka perlu 
Menurut hukum adat, tata cara pemilikan hak atas tanah secara individu dimulai dari seseorang mendapatkan sebidang tanah dan memberikan tanda atas tanah tersebut sebagai tanda penguasaannya. Kemudian dikerjakan sehingga tampak adanya hubungan nyata secara fisik antara seseorang dengan tanah. Berdasarkan kenyataan tersebut ia mengajukan permohonan kepada penguasa adat, bila permohonannya diterima maka sahlah kepemilikannya. Kosekuensinya, ia harus bertanggung jawab atas tanah tersebut dan orang lain harus menghargainya sebagai tanda pengakuan hak seseorang. ${ }^{13}$

Apabila ia tidak bertanggung jawab atas tanah tersebut, atau diterlantarkan sehingga tidak terlihat lagi adanya hubungan nyata secara fisik antara seseorang dengan tanah, maka pemilikan secara individu akan dicabut oleh penguasa adat dan berubah statusnya menjadi hak ulayat, yang bisa diberikan kepada orang lain. Tindakan seperti ini pada masyarakat Tapanuli Selatan disebut dengan "salipi na tartar", biasanya tanah tersebut diberikan kepada orang yang membutuhkan. ${ }^{14}$

dilakukan pembatasan hak menguasai negara atas hak ulayat masyarakat hukum adat. Batasannya adalah kemakmuran rakyat dan terpenuhinya hak asasi manusia. Hak menguasai negara dalam konteks ini perlu memerhatikan empat prinsip: pengakuan terhadap hak ulayat; perlindungan terhadap hak ulayat; pembuatan kebijakan yang terkait masyarakat hukum adat harus partisipatif dan terbuka; dan pembuatan peraturan yang memerhatikan budaya hukum masyarakat hukum tersebut. Muh. Afif Mahfud, "Hak Menguasai Negara dan Perlindungan Hukum terhadap Hak Ulayat Masyarakat Hukum Adat: Kajian Teoritis dan Implementasinya”, Kanun: Jurnal Ilmu Hukum, 19, 1 (2017), hlm. 77.

13 Ter Haar, Asas-asas dan Susunan Hukum Adat, terj. K.Ng Soebakti Poesponoto (Jakarta: Pradnya Paramita, 1960); Bambang Eko Turisno, "Keberlakuan Hukum Adat dan Undang-Undang Pokok Agraria dalam Pembentukan Hak atas Tanah Timbul”, Masalah-Masalah Hukum, 40, 1 (2011), hlm. 47. Bandingkan dengan Ilyas Ismail yang dari penelitiannya terhadap tanah adat di Aceh menyimpulkan lahirnya hak milik berdasarkan hukum adat bukan didasarkan pada keputusan pemberian hak oleh pejabat yang berwenang tetapi hak tersebut tumbuh dan akan meningkat statusnya karena diusahakan secara terus-menerus oleh penggarapnya dengan mengindahkan kaidah-kaidah hukum adat setempat. Ilyas Ismail, "Kajian terhadap Hak Milik atas Tanah yang Terjadi Berdasarkan Hukum Adat", Kanun: Jurnal Ilmu Hukum, 14, 1 (2012), hlm. 7.

14 Ter Haar, Asas-asas dan Susunan Hukum Adat, hlm. 57-58. 


\section{Pola Penguasaan dan Pemilikan Tanah Sawah Gilir Ganti di Kerinci}

Pola penguasaan tanah melalui sistem gilir ganti yang terdapat dalam masyarakat hukum adat ${ }^{15}$ Kerinci pada prinsipnya berkaitan erat dengan sistem kewarisan. Dalam sistem kewarisan masyarakat Kerinci, kedudukan ahli waris perempuan lebih diperhatikan. Hal ini dikarenakan masyarakat di sana menggunakan sistem kekerabatan matrilineal walaupun dirasakan semakin melemah. ${ }^{16}$ Demikian juga perlakuan pada harta-harta peninggalan, ada bagian yang bisa langsung dibagi di antara ahli waris dan terdapat pula bagian harta peninggalan yang hanya diwarisi pada sekumpulan ahli waris. Untuk yang diwariskan pada sekumpulan ahli waris, harta tersebut tidak boleh dibagi di antara mereka tetapi hanya dibagikan/digilirkan pemakaiannya di antara mereka. Harta tersebut tetap dalam status harta waris milik bersama (kolektif), di mana para ahli waris secara individu hanya memiliki hak pakai atas bagian harta waris tersebut.

Dalam hukum waris Kerinci, harta yang akan diwariskan dibagi terlebih dahulu menjadi dua bagian. Bagian pertama disebut dengan harta berat dan bagian kedua disebut dengan harta ringan. Harta berat adalah bagian harta yang nilai ekonomisnya dianggap lebih tinggi dan mampu menjamin kelangsungan hidup suatu keluarga. Bagian dari harta berat ini hanya ada tiga yaitu: rumah kediaman, sawah, dan lumbung padi. Selain dari ketiganya, semuanya dinamai harta ringan.

15 Istilah masyarakat hukum adat merujuk pada: 1) sekumpulan warga yang memiliki kesamaan leluhur (genealogis), 2) tinggal di suatu tempat (geografis), 3) memiliki kesamaan tujuan hidup untuk memelihara dan melestarikan nilai-nilai dan norma-norma, 4) diberlakukan sistem hukum adat yang dipatuhi dan mengikat, 5) dipimpin oleh kepala-kepala adat, 6) tersedianya tempat di mana administrasi kekuasaan dapat dikordinasikan, dan 7) tersedia lembaga-lembaga penyelesaian sengketa baik antara masyarakat hukum adat sesama suku maupun sesama suku berbeda kewarganegaraan. Jawahir Thontowi, "Perlindungan dan Pengakuan Masyarakat Adat dan Tantangannya dalam Hukum Indonesia”, Jurnal Hukum Ius Quia Iustum, 20, 1 (2013), hlm. 28.

16 Bushar Muhammad, Pokok Pokok Hukum Adat (Jakarta: PT. Pradnya Paramita, 1981), hlm. 5. 
Bagian dari harta ringan seluruhnya akan menjadi hak milik saudara laki-laki. Harta tersebut dapat dibagi di antara mereka menjadi hak individu. Apabila di antara ahli waris yang diatur hanya ada seorang saudara perempuan, maka seluruh harta berat jatuh kepadanya. Demikian pula bila ahli waris seluruhnya perempuan, maka seluruh harta berat dibagi rata menjadi hak individu kecuali sawah tetap dipertahankan menjadi hak kolektif yang diatur melalui sistem gilir ganti. Jika seluruh ahli waris adalah laki-laki, maka seluruh harta warisan akan dibagi menurut ketentuan pola kedua (pembagian sama rata) terhadap seluruh harta warisan yang ditinggalkan.

Sawah gilir ganti pada mulanya berstatus tanah sawah hak milik perseorangan atau individu. Setelah terjadi pewarisan atas tanah sawah perseorangan atau individu tersebut, di mana harta waris dibagi menurut ketentuan hukum waris Kerinci yang berpijak pada "Harto berat ditinggal pada anak batino, dan harta ringan dibawo anak jantan”. Ini artinya, harta berat (rumah, sawah dan lumbung padi) diperuntukkan bagi anak perempuan, sedangkan harta ringan (selain harta berat) diberikan kepada anak laki-laki. Khusus untuk sawah tidak boleh dibagi habis di antara saudara perempuan dan diatur pemakaiannya secara bergantian (bergilir). Jadi, sawah-sawah tersebut tidak dibagi menjadi bagian yang lebih kecil lagi oleh ahli waris perempuan, sehingga menjadi milik perseorangan. Sedangkan untuk rumah dan lumbung padi boleh dibagi, asalkan ada persetujuan dari seluruh ahli waris (ahli waris laki-laki dan perempuan).

Mengacu pada ketentuan hukum waris adat sebagaimana telah dijelaskan di atas, maka dapat dikatakan penguasaan dan kepemilikan sawah gilir ganti pada dasarnya menjadi hak milik ahli waris perempuan. Akan tetapi ada klausal lain dari ketentuan hukum adat Kerinci yang mengikat anak perempuan atas hak mereka atas sawah tersebut dengan beberapa tanggung jawab yang melekat.

Pewaris (pemilik hak) sawah gilir ganti adalah anak perempuan, sedangkan penguasaan dan pengaturannya berada pada anak lakilaki. Jika ahli waris laki-laki kemudian hari mempunyai anak perempuan, maka anak perempuan tidak berhak mendapat sawah gilir ganti. Peristiwa ini membuktikan bahwa anak laki-laki bukanlah ahli 
waris dari harta sawah gilir ganti.

Penguasaan dan kepemilikan sawah gilir ganti terlihat tidak sepenuhnya pada anak perempuan. Pemilikan pada anak perempuan sedangkan pengaturannya terletak pada anak laki-laki, walaupun ahli warisnya adalah anak perempuan. Cara penguasaan dan pemilikan seperti ini mengakibatkan pemiliknya tidak leluasa berbuat, karena tidak adanya wewenang penuh yang diberikan kepada pemiliknya, akibat campur tangan anak laki-laki. Campur tangan anak laki-laki ini menyebabkan pola penguasaan dan pemilikan menjadi tidak tegas. Padahal pemberian hak atas tanah kepada seseorang berarti memberikan wewenang kepadanya untuk dapat berbuat sesuatu terhadap tanah yang dikuasainya.

Dalam pola penguasaan sawah gilir ganti, jika ahli waris dari si pewaris (ibunya) tidak ada anak perempuan, maka ia tidak mempunyai hak atas sawah gilir ganti. Apabila anak laki-laki tersebut kemudian mempunyai anak perempuan, anak perempuannya juga tidak mempunyai hak atas sawah gilir ganti. Dengan demikian terputuslah hak gilir ganti pada keluarga bersangkutan, dikarenakan bapaknya (anak laki-laki) bukanlah ahli waris yang secara otomatis anaknya (meskipun ada yang perempuan) tidak berhak atas sawah gilir ganti. Terlihat bahwa hak milik yang sifatnya turun temurun, pada sawah gilir ganti tidak mutlak terjadi, karena alasan tertentu sawah gilir ganti itu tidak diturunkan kepada ahli warisnya. Dengan demikian, dalam hukum waris di Kerinci, harta berat (sawah) hanya diperuntukkan bagi anak perempuan saja, sedangkan anak laki-laki telah ditentukan pula bentuk harta warisannya berupa harta ringan. Berdasarkan hal tersebut, maka hukum waris Kerinci dalam hal pembagian warisan tidak hanya membedakan jenis harta warisan, tetapi juga jenis kelamin ahli warisnya.

Pada saat sekarang apabila terjadi penjualan sawah gilir ganti, maka anak laki-laki selalu mendapat bagian dari penjualan tersebut. Tindakan tersebut seolah-olah bahwa anak laki-laki adalah ahli waris, padahal hukum adat tegas tegas mengatakan bahwa "harto berat tinggal pada anak batino, harto ringan dibawa anak jantan". Pepatah adat tersebut telah membagi secara tegas bahwa harto berat (sawah) 
diwariskan kepada anak perempuan, dan jika dijual, maka hasil penjualannya adalah hak anak perempuan sebagai ahli waris.

Tindakan memberikan hasil penjualan sawah gilir ganti kepada anak laki-laki yang telah dilakukan oleh masyarakat Kerinci, sebenarnya sudah menyimpang dari konsep dasarnya. Karena tindakan ini sering diulang-ulang, maka kesalahan penafsiran terhadap ancaman tersebut seolah-olah dibolehkan masyarakat. Padahal konsep awal ancaman tersebut hanyalah untuk menghalangi agar sawah gilir ganti yang merupakan indikator sebuah ikatan keluarga dialihkan ke pihak lain.

Pada masa sekarang, pola penguasaan tanah sawah secara gilir ganti menghadapi berbagai permasalahan. Efektivitasnya saat ini mulai dipertanyakan. Hal ini disebabkan karena faktor luasan tanah sawah yang terbatas dan jumlah peserta gilir ganti yang semakin bertambah. Luas tanah sawah gilir ganti berkisar lebar lima hingga tujuh meter dan panjang antara 20 sampai 40 meter. Dengan tanah seluas itu, peserta bisa mengerjakannya sesuai dengan jadwal gilirannya dengan mengikuti masa panen, yaitu setahun sekali. Di sisi lain, peserta gilir ganti semakin bertambah seiring turun-temurunnya penguasaan tanah tersebut. Dengan pesertanya 10 orang saja, maka setiap peserta berarti hanya bisa mengerjakan sawah gilir ganti setiap 10 tahun sekali. Oleh sebab itu, jika tanah sawah gilir ganti dimaksudkan untuk kemakmuran masyarakat (petani), maka hal ini tentu bisa dipertanyakan. ${ }^{17}$

Dalam beberapa kasus, gilir ganti sawah juga rentan dengan konflik. Konflik di antara mereka yang berhak atas gilir ganti sering terjadi. Hal ini disebabkan penguasaan sawah gilir ganti sekarang ini sudah pada generasi ketiga atau lebih, sehingga peserta gilir ganti bisa mencapai antara 10 atau 15 orang. Jumlah yang relatif besar ini menyebabkan ada peserta yang tagiling atau lupa memberikan gilirannya, meskipun ketentuannya setiap tahun harus bergantian (bergilir ganti). Dalam beberapa kasus juga ditemukan ada peserta yang setelah gilirannya dan sebelum sempat bergilir ke peserta berikutnya

17 Wawancara dengan Herianto Hamzah, Datuk Kodro Putih dan Tengganai Keluaga, Sungaipenuh, 14/12/2018. 
justru menyuruh orang lain yang tidak berhak untuk mengerjakannya dengan imbalan bagi hasil, di mana ia yang menyuruh mendapat sepertiga bagian sedangkan yang disuruh dua-pertiga bagian. Caracara seperti ini disebut dengan saseh, semacam bagi hasil. Akibatnya, peserta berikutnya yang seharusnya mendapatkan giliran justru tidak bisa mendapatkan haknya. ${ }^{18}$

Konflik juga bisa terjadi dengan sebab beberapa yang berhak atas gilir ganti tidak berdomisili di Kerinci, sekalipun ada dalam Ranji (silsilah keluarga). Mereka ini sering tidak diberikan giliran menggarap sawah oleh penerima sebelumnya atau sesudahnya yang sama-sama tinggal di Kerinci. Biasanya alasan yang disampaikan adalah: mereka yang tidak berdomisili ini dianggap sudah kaya, sehingga tidak memerlukannya lagi. Padahal menurut sejarahnya gilir ganti ini dimaksudkan untuk menandai asal keturunan keluarga yang sama.

Karena tidak terdapatnya ketegasan tentang kepemilikan, penguasaan, dan subjek hak atas sawah gilir ganti, maka menyulitkan untuk mendapat kepastian hak. Sampai saat ini belum ada surat kepemilikan sawah gilir ganti, satu-satunya bukti kepemilikan adalah ranji. Mengingat kebutuhan akan tanah dewasa ini yang semakin meningkat, dan untuk menjaga keamanan dan ketertiban, serta stabilitas di bidang pertanahan, maka semua hak atas tanah perlu didaftarkan untuk mendapatkan kepastian hukum. Untuk mewujudkan cita-cita tersebut, maka setiap hak atas tanah wajib didaftarkan termasuk tanah yang berdasarkan hukum adat.

\section{Sistem Gilir Ganti Sawah dalam Perspektif Hukum Agraria}

UUPA dengan seperangkat peraturan pelaksanaannya bertujuan untuk mewujudkan jaminan kepastian hukum teradap hak-hak atas tanah di seluruh wilayah Indonesia. Jika dihubungkan dengan usaha-usaha pemerintah dalam rangka penataan kembali penggunaan, penguasaan dan pemilikan tanah, maka pendaftaran tanah/pendaf-

18 Wawancara dengan Asmar Malik, Depati Santi Udo Pertamo Alam, Sungaipenuh, 15/12/2018. 
taran hak atas tanah adalah merupakan suatu sarana penting untuk mewujudkan kepastian hukum di seluruh wilayah Republik Indonesia dan sekaligus turut serta dalam penataan penggunaan, penguasaan dan pemilikan tanah. Untuk mewujudkan kepastian hukum, maka hak-hak atas tanah harus didaftarkan agar adanya rasa aman dalam melaksanakan hak dan memberikan perlindungan terhadap hak dan kewajiban tersebut dalam pemanfaatannya dapat membantu usaha peningkatan kesejahteraan rakyat.

Dalam hukum agraria nasional, pendaftaran tanah diatur pada Pasal 19 UUPA: "untuk menjamin kepastian hukum oleh pemerintah diadakan pendaftaran tanah di seluruh wilayah Republik Indonesia menurut ketentuan ketentuan yang diatur dengan Peraturan Pemerintah”. Menurut Peraturan Pemerintah Republik Indonesia Nomor 24 Tahun 1997 tentang Pendaftaran Tanah (PP Pendaftaran Tanah), "pendaftaran tanah adalah rangkaian kegiatan yang dilakukan oleh Pemerintah secara terus menerus, berkesinambungan dan teratur, meliputi pengumpulan, pengolahan, pembukuan, dan penyajian, serta pemeliharaan data fisik dan data yuridis, dalam bentuk peta dan daftar, mengenai bidang-bidang tanah dan satuan-satuan rumah susun, termasuk pemberian surat tanda bukti haknya bagi bidang-bidang tanah yang sudah ada haknya dan hak milik atas satuan rumah susun serta hak-hak tertentu yang membebaninya”.

Pasal 3 PP Pendaftaran Tanah menyebutkan ada tiga tujuan pendaftaran tanah. Pertama, untuk memberikan kepastian hukum dan perlindungan hukum kepada pemegang hak atas atas tanah bidang tanah, satuan rumah susun dan hak-hak lain yang terdaftar agar dengan mudah dapat membuktikan dirinya sebagai pemegang hak yang bersangkutan. Kedua, untuk menyediakan informasi kepada pihak-pihak yang berkepentingan termasuk Pemerintah agar dengan mudah dapat memperoleh data yang diperlukan dalam mengadakan perbuatan hukum mengenai bidang tanah dan satuan-satuan rumah susun yang sudah terdaftar. Ketiga, untuk terselenggaranya tertib administrasi pertanahan.

Menutur Irawan Soerodjo, ada lima keuntungan yang didapat dengan terlaksananya pendaftaran tanah yang baik, yaitu: 
a. Memberikan rasa aman kepada pemegang hak atas tanah karena adanya kepastian hukum mengenai hak atas tanahnya, yang pada gilirannya akan memberikan rasa kemantapan dalam usahanya dan dapat meningkatkan produktifitas dalam pemanfaatan tanah tersebut.

b. Berkurangnya sengketa atas tanah sehingga terdapat penghematan dalam biaya dan waktu bagi perorangan dari aspek mikro maupun bagi negara dari aspek makro.

c. Mudah, murah dan kepastian atas suatu transaksi mengenai tanah. Peralihan hak seseorang atas tanah yang tidak terdaftar seringkali mengakibatkan biaya yang mahal dan menimbulkan ketidakpastian hukum.

d. Meningkatkan investasi dengan menjadikan tanah sebagai jaminan sebelum kredit diberikan.

e. Hasil pendaftaran tanah yang berupa data-data yuridis dan data fisik, selain memberikan kepastian hukum, juga dapat digunakan sebagai instrumen untuk penetapan pajak tanah. ${ }^{19}$

Selama ini pendaftaran tanah berlangsung sangat lambat, karena pemerintah melaksakan prinsip sistem pendaftaran negatif yang dilakukan secara sporadis, yaitu pendaftaran tanah dilakukan terhadap orang yang mengajukan pendaftaran tanah. Di samping itu dibantu dengan Prona yang dilakukan setiap hari ulang tahun hukum agraria tanggal 24 September, pendaftaran sistem negatif ini berjalan secara lamban, kalau sistem ini dijalankan maka Indonesia akan bisa mencapai sertifikasi tanah secara menyeluruh sekitar 200 tahun lagi.

Untuk mengatasi lambannya pendaftaran tanah maka pemerintah saat ini membentuk kementerian baru bernama Kementerian Agraria dan Tata Ruang Indonesia, sehingga sejak 27 Oktober 2014, Badan Pertanahan Nasional berada di bawah naungan Menteri Agraria dan Tata Ruang. Program yang sangat populer saat ini adalah Program Pendaftaran Tanah Sistem Lengkap atau yang dikenal dengan PTSL. Program ini untuk menyisir seluruh wilayah terdata melalui mekanisme sertifikasi secara keseluruhan. Program ini di-

19 Irawan Soerodjo, Kepastian Hukum Hak Atas Tanah di Indonesia (Surabaya: Arkola, 2002), hlm. 27. 
harapkan dapat mempercepat memenuhi kebutuhan masyarakat akan legalitas sebuah investasi.

Untuk mengatasi sistem pendaftaran tanah yang tadinya rumit dan hanya menunggu inisiatif dari masyarakat, PTSL kini bahkan melakukan mekanisme jemput bola. Tim satgas dari BPN yang berpusat di setiap kantor kelurahan daerah nantinya akan bekerja sama dengan kelurahan untuk mendata wilayah yang belum disertifikasi. Program ini melayani seluruh masyarakat baik yang mampu maupun yang tidak mampu. Segala pembiyaan administrasi di Kantor Badan Pertanahan Nasional untuk mekanisme sertifikasi seperti biaya ukur, biaya panitia pemeriksa tanah sampai biaya administrasi pendaftaran, di seluruh cabang di Indonesia dibayarkan dari APBN.

Menurut kepala Badan Pertanahan Nasional Kota Sungai Penuh, Gustizar, pemerintah menargetkan 126 juta bidang tanah sudah bersertifikasi pada tahun 2024, termasuk wilayah Kota Sungai Penuh ditargetkan 6000 tanah sudah bersertifikasi pada tahun 2017, 8000 pada tahun 2018, dan 9000 pada tahun 2019. ${ }^{20}$ Untuk Kota Sungai Penuh, target yang dibebankan oleh pemerintah tersebut tidak bisa dipenuhi dikarenakan terkendala oleh ketidakpastian tentang penguasaan dan pemilikan hak atas tanah yang berdasarkan hukum adat, salah satunya adalah penguasaan dan pemilikan hak tanah berdasarkan pola penguasaan tanah sawah gilir ganti. Tanah sawah gilir ganti cukup banyak di Kota Sungai Penuh, yaitu sekitar 30 persen dari total sawah yang ada, dan sampai hari ini tidak satupun yang bisa disertifikasi. ${ }^{21}$

Tanah sawah gilir ganti tidak bisa didaftarkan dikarenakan tidak jelas subjek hukumnya, sedangkan pendaftaran tanah justru menghendaki adanya kepastian hukum tentang subjek hukumnya. Menurut Maria SW Sumardjono, ketika berbicara tentang "hak", ada empat unsur yang harus dipenuhi: subyek, obyek, hubungan hukum yang mengikat pihak lain dengan kewajiban, dan perlindungan hukumnya. Unsur subyek di sini menempati kedudukan terpenting,

20 Wawancara dengan Gustizar, Kepala Badan Pertanahan Nasional Kota Sungai Penuh, Sungai Penuh, 9/7/2018.

21 Wawancara dengan Gustizar, Kepala Badan Pertanahan Nasional Kota Sungai Penuh, Sungai Penuh, 9/7/2018. 
karena ketidakjelasan subyek akan berimbas pada ketidakjelasan tiga unsur lainnya. ${ }^{22}$

Secara fisik tanah sawah gilir ganti dikelola dan dinikmati hasilnya oleh ahli waris anak perempuan, sedangkan pengaturannya oleh tengganai (saudara laki laki dari pihak ibunya). Menurut pepatah adatnya "harto berat untuk batino, harto ringan dibawo jantan". Berdasarkan seloko tersebut, maka subjek hukum dari tanah tersebut adalah anak perempuan. Sesuai ketentuan Pasal 20 UUPA, maka yang memiliki hak dan kewenangan atas tanah tersebut adalah ahli waris anak perempuan. Namun demikian, menurut hukum adat Kerinci justru kewenangan berada pada saudara laki-laki dari pihak ibunya. Pada sisi lain apabila tanah sawah gilir ganti dijual, maka ahli waris anak laki-laki berhak mendapatkan bagiannya, sehingga tidak jelas siapa sebenarnya subjek hukumnya.

Upaya untuk mendorong pendaftaran tanah di Sungai Penuh sebagai wilayah pecahan Kabupaten Kerinci hingga saat ini ialah, ada sebagian orang adat yang tidak mau menerima atau merobah hukum adat yang berlaku dengan prinsip "dicabut mati, diasak layu", yang berarti hukum adat yang berlaku pada masyarakat adalah statis tidak boleh diganggu gugat, tidak terpengaruh oleh dinamika perkembangan hukum dalam masyarakat, termasuk juga pengaruh hukum agraria nasional. Ada juga sebagian orang adat yang mau menerima perubahan, dan menyesuaikan dengan berlakunya hukum agraria nasional, namun terhalang dengan pihak lainnya yang masih ingin mempertahankannya. Sebagian lagi ada yang mau menerima perubahan, dengan pertimbangan produktivitas pemanfaatan tanah, ketertiban dan kepastian hukum atas tanah. ${ }^{23}$

Dengan demikian, ditinjau dari hukum agraria nasional, maka pola penguasaan tanah sawah secara gilir ganti sulit untuk diberikan kepastian hukum berupa pendaftaran tanah. Alasannya karena subyek hukum atas tanah itu akan sulit diidentifikasi, terlebih untuk se-

22 Maria SW Sumardjono, "Ihwal Hak Komunal atas Tanah", Digest Epistema, 6 (2016), hlm. 4.

23 Wawancara dengan Gustizar, Kepala Badan Pertanahan Nasional Kota Sungai Penuh, Sungai Penuh, 9/7/2018. 
bagian tanah sudah digarap oleh generasi ketiga dan bahkan lebih. Hak milik dalam hukum agraria yang memberi hak dan kewenangan yang sangat kuat kepada pemiliknya juga sulit diterapkan pada tanah sawah gilir ganti, disebabkan tanah tersebut berada dalam kekuasaan anak perempuan namun tetap memberi kewenangan kepada ahli waris anak laki-laki, sesuai adat Kerinci bahwa pihak yang memiliki kewenangan dalam suatu keluarga ialah laki-laki. Hal ini tentu bisa menyebabkan hukum adat gilir ganti menjadi tersudutkan manakala ditinjau dari hukum agraria nasional yang mengedepakan kepastian. ${ }^{24}$

\section{E. Penutup}

Artikel ini menyimpulkan, pertama, penguasaan dan pemilikan hak atas tanah secara hukum adat dibenarkan oleh hukum agraria nasional dan diakui keberadaannya untuk mengatur pertanahan pada masyarkat persekutuan hukum adat sepanjang tidak bertantangan dengan kepentingan bangsa dan negara dan dengan peraturan yang ada sesuai dengan hirarki hukum nasional. Sistem gilir ganti adalah salah satu bentuk penguasaan dan pemilikan tanah secara hukum adat yang terdapat di Kerinci yang dipengaruhi oleh sistem kekerabatan dan kewarisan yang membedakan antara anak laki-laki dan anak perempuan. Tanah sawah dikerjakan dan dinikmati oleh anak perempuan sedangkan pengaturannya dilakukan oleh saudara lakilaki atau yang disebut dengan tengganai. Semakin banyak ahli waris perempuan maka semakin lama pula masa tunggu. Sistem ini telah berlangsung dari nenek moyang dahulu yang menyebabkannya saat

$24 \mathrm{Hal}$ ini memperkuat kesimpulan Darwin Ginting bahwa perlindungan terhadap eksistensi dan hak-hak masyarakat hukum adat merosot tajam sejak tahun 1960, seiring dengan meningkatnya kepentingan negara terhadap sumber daya alam, yang terdapat dalam wilayah hak ulayat masyarakat hukum adat, terutama di luar Pulau Jawa. Dengan berbagai peraturan perundang-undangan, negara mengambil berbagai kebijakan yang intinya adalah mengurangi, membatasi hak-hak tradisional serta hak masyarakat hukum adat yang ada. Darwin Ginting, "Politik Hukum Agraria terhadap Hak Ulayat Masyarakat Hukum Adat di Indonesia", Jurnal Hukum dan Pembangunan, 42, 1 (2012), hlm. 30. 
ini tidak efektif, tidak produktif, rawan konflik, dan tidak memiliki kepastian hukum. Kedua, pola penguasaan dan pemilikan tanah seperti itu menyebabkan tidak bisa memastikan subjek hukumnya, yang merupakan salah satu syarat dalam pendaftaran tanah. Namun demikian, sistem ini masih bertahan dan dipertahankan hingga sekarang, dengan alasan sebagai penanda dari keturunan keluarga yang sama.

\section{Daftar Pustaka}

\section{Artikel/Buku/Laporan}

Abubakar, Lastuti. "Revitalisasi Hukum Adat Sebagai Sumber Hukum dalam Membangun Sistem Hukum Indonesia”. Jurnal Dinamika Hukum, 13, 2 (2013): 319-331. DOI: 10.20884/1. jdh.2013.13.2.213

Alting, Husen. "Penguasaan Tanah Masyarakat Hukum Adat (Suatu Kajian terhadap Masyarakat Hukum Adat Ternate)". Jurnal Dinamika Hukum, 11, 1 (2011): 87-98. DOI: 10.20884/1. jdh.2011.11.1.75

Djakfar, Idris. "Hukum Waris Adat Masyarakat Kerinci”. Laporan Penelitian, Fakultas Hukum Universitas Jambi, 1992.

Ginting, Darwin. "Politik Hukum Agraria terhadap Hak Ulayat Masyarakat Hukum Adat di Indonesia”. Jurnal Hukum dan Pembangunan, 42, 1 (2012): 29-53.

Hadikusuma, Hilman. Pengantar Ilmu Hukum Adat Indonesia. Bandung: Mandar Maju, 1994.

Ismail, Ilyas. "Kajian terhadap Hak Milik atas Tanah yang Terjadi Berdasarkan Hukum Adat”. Kanun: Jurnal Ilmu Hukum, 14, 1 (2012): 1-11.

Koentjaraningrat. Kebudayaan, Mentalitet, dan Pembangunan. Jakarta: PT Gramedia, 1987.

Mahfud, Muh. Afif. "Hak Menguasai Negara dan Perlindungan Hukum terhadap Hak Ulayat Masyarakat Hukum Adat: Kajian Teoritis dan Implementasinya”. Kanun: Jurnal Ilmu Hukum, 19, 1 (2017): 63-79. 
Maladi, Yanis. "Reforma Agraria Berparadigma Pancasila dalam Penataan Kembali Politik Agraria Nasional”. Mimbar Hukum, 25, 1 (2013): 27-41. DOI: $10.22146 /$ jmh.16108

Mudjiono. "Eksistensi Hak Ulayat dalam Pembangunan Daerah". Jurnal Hukum Ius Quia Iustum, 25, 11 (2004): 152-166.

Muhammad, Bushar. Pokok-pokok Hukum Adat. Jakarta: PT. Pradnya Paramita, 1981.

Soerodjo, Irawan. Kepastian Hukum atas Tanah di Indonesia. Surabaya: Arloka, 2002.

Sukirno. "Kebijakan Afirmatif Pengakuan dan Perlindungan Hakhak Masyarakat Hukum Adat". Masalah-Masalah Hukum, 44, 3 (2015): 326-335. DOI: 10.14710/mmh.44.3.2015.326-335

Sumardjono, Maria SW. "Ihwal Hak Komunal atas Tanah". Digest Epistema, 6 (2016): 4-6.

Sutedi, Adrian. Peralihan Hak Atas Tanah dan Pendaftarannya. Jakarta: Sinar Grafika, 2006.

Syamsudin, M. "Beban Masyarakat Adat Menghadapi Hukum Negara”. Jurnal Hukum Ius Quia Iustum, 15, 3 (2008): 338-351. DOI: 10.20885 / iustum.vol15.iss3.art9

Thontowi, Jawahir. "Perlindungan dan Pengakuan Masyarakat Adat dan Tantangannya dalam Hukum Indonesia”. Jurnal Hukum Ius Quia Iustum, 20, 1 (2013): 21-36. DOI: 10.20885/iustum.vol20. iss1.art2

Turisno, Bambang Eko. "Keberlakuan Hukum Adat dan UndangUndang Pokok Agraria dalam Pembentukan Hak atas Tanah Timbul”. Masalah-Masalah Hukum, 40, 1 (2011): 46-52. DOI: $10.14710 / \mathrm{mmh} .40 .1 .2011 .46-52$

\section{Peraturan Hukum}

Republik Indonesia. Undang-undang Nomor 5 Tahun 1960 tentang Peraturan Dasar Pokok-pokok Agraria.

Republik Indonesia. Peraturan Pemerintah Nomor 24 Tahun 1997 tentang Pendaftaran Tanah. 


\section{Hasil Wawancara}

Hasil wawancara dengan Asmar Malik, Depati Santi Udo Pertamo Alam, Sungai Penuh, 15/12/2018.

Hasil wawancara dengan Gustizar, Kepala Badan Pertanahan Nasional Kota Sungai Penuh, Sungai Penuh, 9/7/2018.

Hasil wawancara dengan Herianto Hamzah, Datuk Kodro Putih dan Tengganai Keluaga, Sungai Penuh, 14/12/2018. 